\title{
<シンポジウム 10>神経機能画像の進歩
}$$
\text { オーバービュー }
$$ \\ 座長 東北大学大学院医学系研究科高次機能障害学森悦朗 \\ 京都大学医学研究科附属高次脳機能総合研究センター 福山 秀直
}

（臨床神経，49：921, 2009）

脳機能画像の進歩は，これまでの機能的 MRI や PET の脳 賦活試験のみならず, 神経疾患における病態の解明から治療 の評価まで, 広沉な進歩を示している. 本シンポジウムでは, 機能的 MRI などの注意点として，もっとも基本となる $2 X 2$ のパラダイムを考案することが重要であることを, 東北大学 の藤井俊勝先生にわかりやすく解説していただいた.これは, 重要な点で, 脳がなにもしないということはないので, きちん とした脳機能を見るためには, rest ではなく, 差分をとったば あい，目的となる現象が残るようなパラダイムを作成するこ とが必要である.

さらに, 東北大学の岡村信行先生には, $\mathrm{BF} 227$ から $\mathrm{PIB}$ の脳アミロイドイメージングを説明していただいた.とくに, BF227 は日本で開発されたトレーサーで, PIB が原始プラー クも画像化するのに対し，BF は老人斑をイメージングする ので, 確実にアルッハイマー病の診断できる特徴がある.アル ッハイマー病などに関連して, 浜松医科大学の尾内康臣先生 は，ミクログリアの画像化をPK11195をもちいておこない， 神経変性疾患といわれていたものも, 軽度の炎症反応をとも なって㧍り,ミクログリアが生体予防的に働いているか, 生体 攻撃的に㗢くか，区別できるトレーサーが開発されていない
が,これが可能になれば, 疾患の治療にも役立つ可能性を示唆 した.

放医研の樋口真人先生は, アルッハイマー病の病態を分子 イメージング手法で研究した成果から, APP の分解に関与す る $\mathrm{QC}$ と呼ばれる䤏素が，ネプリライシンとはことなった代 謝経路の分解に関与して打り，その阻害作用をもつ PBP150 を使うことで, ベータアミロイドへ分解代謝が変化している のを, 正常化できる可能性を示し,これからの新しいアルッハ イマー病の治療の可能性を示唆した.

これまでは, 脳の機能局在や相互の結合などに研究の主眼 が置かれていたが, これからは, 疾患モデル動物・ヒトを対象 にして, 病態の本質に迫る研究の一翼を担うことができるこ とが示唆された. PETではオートラジオグラフィーとことな り, 経時的な変化を追うことが可能であり, また, 非常に高感 度, 高分解能の機器が利用できるようになったことが大きな 要因であり，また，放射性化合物合成手法の進歩も大きな原因 である. かかる医工連携の成果として，今後さらに大きな発 展, 発見があることが期待される分野であり,多くの研究者の 注目するところとなっている. 